\title{
The repellency and toxicity effects of essential oils from the Libyan plants Salvadora persica and Rosmarinus officinalis against nymphs of Ixodes ricinus
}

\author{
Fawzeia Elmhalli, ${ }^{10}$ - Samira S. Garboui ${ }^{2} \cdot$ Anna-Karin Borg-Karlson ${ }^{3}$. \\ Raimondas Mozūraitis ${ }^{4}$. Sandra L. Baldauf ${ }^{1}$. Giulio Grandi ${ }^{5}$
}

Received: 27 February 2019 / Accepted: 7 May 2019 / Published online: 14 May 2019

(C) The Author(s) 2019

\begin{abstract}
Essential oils extracted from the leaves of Libyan Rosemary (Rosmarinus officinalis L.), and Miswak (Salvadora persica L.) were evaluated for their acaricidal and repellent effects on Ixodes ricinus L. nymphs (Acari: Ixodidae) using a bioassay based on an 'open filter paper method'. Rosmarinus officinalis leaf essential oil diluted to 0.5 and $1 \mu \mathrm{l} / \mathrm{cm}^{2}$ in acetone exhibited, respectively, 20 and $100 \%$ tick mortality after about $5 \mathrm{~h}$ of exposure. A total of 50 and $95 \%$ of I. ricinus nymphs were killed by direct contact with the oil when exposed to lethal concentrations (LC) of $0.7 \mu \mathrm{l} / \mathrm{cm}^{2}\left(\mathrm{LC}_{50}\right)$ and $0.95 \mu \mathrm{l} / \mathrm{cm}^{2}\left(\mathrm{LC}_{95}\right)$, respectively. The $\mathrm{LC}_{50}\left(0.5 \mu \mathrm{l} / \mathrm{cm}^{2}\right)$ was reached before the end of the first $24 \mathrm{~h}$ of exposure time (ET), as tick mortality at $24 \mathrm{~h}$ was $60 \%$. Salvadora persica leaf essential oil at $1 \mu \mathrm{l} / \mathrm{cm}^{2}$ showed a significant repellency effect against I. ricinus nymphs at $1.5 \mathrm{~h}$ ET. A $95 \%$ repellency was observed at a repellent concentration $\left(\mathrm{RC}_{95}\right)$ of $1 \mu \mathrm{l} / \mathrm{cm}^{2}$ of $S$. persica, but no significant mortality was recorded at this dose of $S$. persica oil. Gas chromatography-mass spectrometry analyses showed that the main monoterpenes in both oils were 1,8-cineol, $\alpha$-pinene, and $\beta$-pinene, although in markedly different proportions. These results suggest that essential oils have substantial potential as alternative approaches for I. ricinus tick control.
\end{abstract}

Keywords Rosmarinus officinalis $\cdot$ Salvadora persica $\cdot$ Essential oils $\cdot$ Acaricidal $\cdot$ Ixodes ricinus

Fawzeia Elmhalli

fawzeia.elmhalli@ebc.uu.se

1 Department of Systematic Biology, Evolutionary Biology Centre, Uppsala University, Norbyvägen 18d, 75236 Uppsala, Sweden

2 Department of Environmental Health, Department of Infectious Diseases and Tropical Diseases, Faculty of Public Health, University of Benghazi, Benghazi, Libya

3 Department of Chemistry, School of Engineering Sciences in Chemistry, Biochemistry and Health, Royal Institute of Technology, KTH, Stockholm, Sweden

4 Department of Zoology, Stockholm University, Stockholm, Sweden

5 Department of Biomedical Sciences and Veterinary Public Health, Swedish University of Agricultural Sciences (SLU), Uppsala, Sweden 


\section{Introduction}

Many plant essential oils show a broad spectrum of effects against arthropods pests, including anti-feedant, repellent, and growth regulatory and anti-vector activity. Previous investigations indicate that some chemical constituents of these oils interfere with the octopaminergic nervous system of the insects (Bischof and Enan 2004; Kostyukovsky et al. 2002), which has the advantage of being a target site not shared with mammals. In fact, most essential oils have been shown to be relatively non-toxic to mammals and fish, and thus meet the criteria for "reduced risk" pesticides (Stroh et al. 1998). Part of the explanation for this success is the unique repertoire of diverse chemical structures that can be found in nature. Examples include azadirachtin, isolated from the neem tree, and other bioactive compounds that have been used successfully for pest control (Isman et al. 1990; Park et al. 2003; Wang et al. 2010). In Libya, many plants have medicinal or economic importance and have had a deep impact on the life and culture of the Libyan people. For example, Salvadora persica, commonly known as Miswak, is used for its antibacterial effect on several oral bacteria (Alali and Al-Lafi 2003; Sofrata 2010).

Rosmarinus officinalis is an aromatic herbal remedy that can relieve cramps and pain, and improve the circulation to the head. Thus its common name in Arabic translates to "herb of remembrance" (Begum et al. 2013). It also stimulates the liver and gallbladder, and improves digestion by controlling pathogenic organisms. The plant parts used include leaves and flowers, which contain essential oils in several species of Rosemary (Rosmarinus spp.). This special combined with the wide availability of essential oils from the flavor and fragrance industries, has made it possible to fast track commercialization of essential oil-based pesticides or acaricides.

Ticks (Acari: Ixodoidea) and tick-borne diseases are distributed worldwide (Ghosh et al. 2007). In recent years these have received increasingly serious attention because of their expanding territories (Bueno-Marí 2013; Bueno-Marí et al. 2015) and impact on public health (Estrada-Peña and Jongejan 1999; Jongejan and Uilenberg 2004). Tick-borne diseases such as the bacterial Lyme disease and the viral tick-borne encephalitis (TBE) have received greater attention as the number of cases increases every year (Centers for disease control and prevention (cdc) 2017). Thus, the discovery of effective and environmentally safe tick-repellents and pesticides (acaricides) has become more urgent. At the same time, public concerns about the environmental impact and safety of chemical applications are driving research into alternative, sustainable methods for pest control, such as plant-based acaricides.

One of the most common tick species is Ixodes ricinus L. (Acari: Ixodidae), which occurs over a wide geographical range, from Ireland in the west to the Ural Mountains (Russia) in the east, and from Scandinavia in the north to Morocco and Egypt in the south (Estrada-Peña et al. 2018). Ixodes ricinus (L.) can transmit Lyme borreliosis (LB), caused by the spirochete Borreliella burgdorferi and affecting 100,000-200,000 people every year in Europe (Pålsson et al. 2008). Pathogens known to be carried by this species are tickborne encephalitis virus (TBEV) (Pritt et al. 2016), ehrlichiosis, tularaemia, rickettsiosis, and babesiosis (Aberer 2009). Ixodes ricinus has increased its known geographical distribution and density-activity in many areas of Europe in the last decades, possibly due at least partly to the changing climate (Lindgren et al. 2000; Jaenson et al. 2012; Medlock et al. 2013). This is reflected in an increasing number of reported cases of tick-borne diseases (Michelet et al. 2014). Examples from Scandinavia include a correlation between changes in tick distribution or abundance (Mannelli et al. 2012) and the incidence of LB 
and TBE (Lindgren and Gustafson 2001). Further, studies from the Czech Republic show the occurrence of I. ricinus and TBE cases has shifted in recent decades to include higher altitudes, probably due to a prolonged vegetation period, in particular milder autumns (Mannelli et al. 2012).

The nymphal stage of I. ricinus is the most medically relevant. Nymphs can transmit the same diseases as adults (Heyman et al. 2010), and they are more abundant. The much smaller size of nymphs compared to adult ticks also means that the nymphs are much harder to detect and therefore less likely to be removed before transmission occurs. Thus nymphs probably pose more of a risk than adult ticks (Randolph 1998). Nymphs of I. ricinus feed for 5-10 days during spring-summer before dropping to the ground and moulting to adults. The multi-host behaviour of I. ricinus also gives it considerable opportunities to spread pathogens among numerous animal species including humans (Bischof and Enan 2004). Since the human risk of acquiring tick borne diseases transmitted from biting by $l$. ricinus is broadly linked to tick nymph density (Lindgren et al. 2000), we focused on the nymphal stage in this study. This is considered the most important stage of ticks as a vector of disease in humans.

\section{Materials and methods}

\section{Tick collection and preservation}

Unfed nymphs of $I$. ricinus were collected in a woodland area 6-8 $\mathrm{km}$ south of Uppsala $\left(59.85862^{\circ} \mathrm{N}, 17.64373^{\circ} \mathrm{E}\right)$ in east-central Sweden, during April-September 2016 by dragging a $1 \mathrm{~m}^{2}$ light-coloured flannel cloth over the ground vegetation (Mejlon and Jaenson 1993). The cloth was inspected at each $10 \mathrm{~m}$ step, at which time all nymphs adhering to the cloth were collected. Nymphs were maintained at $85-95 \%$ relative humidity (RH) and $\approx 4{ }^{\circ} \mathrm{C}$ in complete darkness for 2 months. Before testing, the nymphs were allowed to adapt to the test environment $\left(21-23^{\circ} \mathrm{C}, 85-95 \% \mathrm{RH}\right)$ for $24 \mathrm{~h}$.

\section{Plant material}

Plant materials were collected as wild grown material in the Green Mountain (Al-Jabaal Al-Akhder), a heavily forested fertile upland area in northeaster Libya. The collection consisted of two plants, S. persica (Salvadoraceae) and $R$. officinalis (Labiatae/Lamiaceae). Plant leaves were stored in polyethylene bags in a freezer at $-20{ }^{\circ} \mathrm{C}$, before steam distillation within 30 days. The yield from $100 \mathrm{~g}$ of fresh leaves of $R$. officinalis and S. persica was 2.05 and $0.07 \mathrm{~g}$ of essential oil, respectively (Table 1).

Table 1 Local names and essential oil yield for the two Libyan plants studied

\begin{tabular}{llllll}
\hline No. & Latin name & Local name & Part used & Weight $(\mathrm{g})$ & Oil yield (g) \\
\hline 1 & Rosmarinus officinalis & Ikleel & Leaves & 100 & 2.05 \\
2 & Salvadora persica & Miswak & Leaves & 100 & 0.07 \\
\hline
\end{tabular}




\section{Essential oils}

Oils were prepared by steam distillation from leaves and stems, which were placed in a glass vessel. Steam produced in a separate container at elevated pressure was then introduced into the vessel. After about $4 \mathrm{~h}$ exposure time, the steam was collected and cooled in a Liebig cooler, and the oil/water mixture was collected in glass vials. The oil was then extracted with $n$-pentane 99)\%) and dehydrated with $\mathrm{MgSO}_{4}$, after which the mixture was filtered and weighed (Table 1).

\section{GC-MS analysis}

The essential oils were analysed by a gas chromatograph coupled with a mass spectrometer (GC-MS). The oil was diluted with hexane and around $300 \mathrm{ng} / 1 \mu \mathrm{l}$ was injected syringe into a Hewlett Packard GC 6890 N (Agilent Technologies, USA) equipped with a DB-5 column (30 m length, $0.25 \mathrm{~mm}$ internal diameter and $0.25 \mu \mathrm{m}$ stationary phase film thicknesses, Agilent Technologies) for separation of the volatiles. The GC injector temperature was set up at $250{ }^{\circ} \mathrm{C}$ and held isothermally throughout the analysis. The $\mathrm{GC}$ oven temperature was held isothermally at $40{ }^{\circ} \mathrm{C}$ for $2 \mathrm{~min}$, followed by an increase of $4{ }^{\circ} \mathrm{C} \mathrm{min}^{-1}$ up to $200{ }^{\circ} \mathrm{C}$, followed by an increase of $10^{\circ} \mathrm{C} \mathrm{min}{ }^{-1}$ up to $280{ }^{\circ} \mathrm{C}$, and then held isothermally at $280{ }^{\circ} \mathrm{C}$ for $10 \mathrm{~min}$. High purity helium gas (5.0 Lab Line, Strandmøllen, Denmark) was used as the mobile phase with a constant flow of $1 \mathrm{ml} / \mathrm{min}$. The ion source of the Hewlett Packard 5973 mass spectrometer (Agilent Technologies) was operated at $230{ }^{\circ} \mathrm{C}$, with an electron ionization energy of $70 \mathrm{eV}$ and a solvent delay of $5 \mathrm{~min}$. All compounds were identified by comparing their mass spectra and retention indexes with those presented in the NIST-2008 MS library, published retention index values and available authentic standards using MSD Productivity ChemStation (v.02.01.1177). The quantitative composition of essential oil was reported as a relative percentage of the total peak area.

\section{Laboratory bioassays}

Acaricidal and repellency effects were evaluated using an 'open filter paper method' (WHO 1996). For $S$. persica, $64 \mu \mathrm{l}$ oil was diluted in $1 \mathrm{ml}$ of acetone, and tested in three replicates at a concentration of $1 \mu \mathrm{l}$ oil per $\mathrm{cm}^{2}$ of filter paper. For $R$. officinalis 64 and $32 \mu \mathrm{l}$ of oil were diluted in $1 \mathrm{ml}$ acetone to give concentrations of 1 and $0.5 \mu \mathrm{l} / \mathrm{cm}^{2}$. Each oil acetone mix was uniformly spread with a micropipette onto a round Whatman filter paper no. 1 $(64 \mathrm{~cm})$ and air dried for $20 \mathrm{~min}$. Filter paper impregnated with solvent (acetone) was used as control. Each replicate consisted of 10 nymphs selected randomly and introduced into a plastic cup with a single piece of filter paper sitting on the bottom. The plastic cups were covered by fine-meshed cloth with rubber bands around the rim to prevent the ticks from escaping. Each cup was placed separately in a closed container with wet toilet paper at the bottom to maintain an appropriate humidity.

Repellency was determined by recording nymphal behaviour. Non-repelled nymphs were those that moved freely in the cup throughout the trial period, while nymphs that moved to the top edges of the cup were considered 'repelled'. Nymphs were checked every $30 \mathrm{~min}$ for $6 \mathrm{~h}$. This is the minimum amount of time observed for transmission of Borrellia while most studies indicate that Borrellia are required at least $24 \mathrm{~h}$ for transmission (Cook 2015; Hynote et al. 2012; Strle et al. 1996). 
Nymph mortality was assessed every 30 min up to $5 \mathrm{~h}$, and then checked every $24 \mathrm{~h}$ after (Table 3). Prior to mortality ticks tended to show toxicity effects, particularly changes in their movement and behaviour such as trembling, knockdown and paralysis. Mortality was assessed by visual inspection and light microscopy and by prodding with a pin. All tests were repeated three times and were performed in the laboratory at $20-21{ }^{\circ} \mathrm{C}$ and $89-97 \%$ relative humidity.

Tick mortality and repellency were calculated as follows:

$$
\begin{gathered}
\% \text { Mortality }=[\text { (no. of dead nymphs in the test } \\
- \text { no. of dead nymphs in the control }) \\
\quad \div \text { total no. of nymphs })] \times 100 \\
\% \text { Repellency }=[\text { (no. of nymphs on cup rim } \\
- \text { no. of nymphs on cup rim in the control) } \\
\div \text { total no. of nymphs used }] \times 100 .
\end{gathered}
$$

Dose-response curves were obtained by plotting the percentage mortality for each exposure time versus oil concentration, with the slope of the line calculated. $\mathrm{LC}_{50}$ and $\mathrm{LC}_{95}$ were then determined from these curves. Time-response curves were obtained by plotting percentage mortality versus exposure time for each concentration. $\mathrm{LT}_{50}$ and $\mathrm{LT}_{95}$ were then determined from the resulting curves (Oris and Bailer 1997).

\section{Statistical analyses}

Groups were compared using a one-way ANOVA with multiple regression test. Variances were compared using an $\mathrm{F}$ test, and $t$ test was used for determining equality of means. Shared variance $\left(\mathrm{R}^{2}\right)$ was also estimated to account for the effect of the different oils. A value of $\mathrm{p}<0.05$ was considered significant. All statistical analyses were carried out using Prism 7 for Windows (Graph Pad Software, USA).

\section{Results}

\section{Extraction of essential oils}

Two plants widely used in traditional medicine in Libya were studied, $R$. officinalis and $S$. persica. Extracts from both planted were assayed for their possible repellency and acaricidal effects against nymphs of the widespread common tick, I. ricinus. A total of $100 \mathrm{~g}$ of fresh leaves were collected in Libya for each plant. After extraction yielded essential oils in the amounts of $2.05 \mathrm{~g}$ from $R$. officinalis and $0.07 \mathrm{~g}$ from $S$. persica (Table 1).

\section{GC-MS analysis of plant oils}

Extracted oils were analysed by GC-MS to determine their chemical composition by retention time and comparison to known standards. A total of 29 compounds were identified from $S$. persica, corresponding to $98.34 \%$ of all the compounds detected by GC-MS. The 
most abundant of these were (2E)-Hexenal (32.7\%), 1.8-cineol (20.8\%), $\beta$-pinene (16.8\%), and $\alpha$-pinene (5.9\%). Together these account for $75.5 \%$ of the total ion current (TIC). For $R$. officinalis, 28 compounds were identified, corresponding to $98.23 \%$ of the TIC. The majority of the detected compounds were oxygenated monoterpenes and monoterpene hydrocarbons in different proportions. The most abundant of these were 1,8-cineole (26.76\%), $\alpha$-pinene (13.03\%), verbenone (11.51\%) and borneol (7.08\%), constituting 58.3\% of the oil. The main volatile compounds of $S$. persica and $R$. officinalis essential oils and their relative percentage based on the TIC chromatogram are shown in Table 2.

Overall, the volatile compound composition of $R$. officinalis was more diverse than that of $S$. persica. Nonetheless, both plants showed a large component of 1,8-cineole, which was the major constituent in R. officinalis (26.76\% of TIC) and the second most abundant constituent in $S$. persica (20.8\% of TIC). Both plant oil extracts also showed a substantial amount of $\alpha$ - and/or $\beta$-pinene (16.8\% $\alpha$ - and $5.9 \% \beta$-pinene in S. persica; $13.03 \% \alpha$-pinene in $R$. officinalis. However, the major constituent in S. persica oil was (2E)-Hexenal, which was absent in $R$. officinalis oil (Table 2).

\section{Bioassays of oil toxicity against ticks}

To assay possible toxicity effects of the oils against $I$. ricinus, nymphs were subjected to various length exposures to the oils and their survival recorded. For $R$. officinalis oil, mortality was assayed at doses of 1.0 and $0.5 \mu \mathrm{l} / \mathrm{cm}^{2}$ of. At $1.0 \mu \mathrm{l} / \mathrm{cm}^{2}$, the ticks remained alive during the first hour but had already stopped all movement and appeared paralyzed but trembling when prodded with a pinpoint tool. Mortality started to appear in the second hour and $50 \%$ mortality $\left(\mathrm{LC}_{50}\right)$ was reached between the third and the fourth hour of exposure (Fig. 1). To get a more precise estimate of optimal exposure time and concentration, mortality was plotted against oil concentration for various exposure times, and LC and LT values were calculated from the curves (Fig. 2). The $\mathrm{LC}_{50}$ and $\mathrm{LC}_{95}$ are estimated to be 0.7 and $0.95 \mu \mathrm{l} / \mathrm{cm}^{2}$, respectively, and the $\mathrm{LT}_{50}$ and $\mathrm{LT}_{95}$ for $1.0 \mu \mathrm{l} / \mathrm{cm}^{2} R$. officinalis oil are estimated to be 3.75 and $4.5 \mathrm{~h}$, respectively (Table 3 ). Statistical testing confirmed that $R$. officinalis at $1 \mu \mathrm{l} / \mathrm{cm}^{2}$ has a significant toxic effect within $24 \mathrm{~h}(\mathrm{~F}=1559, \mathrm{DF}=20$, $\mathrm{t}=4.346, \mathrm{R}^{2}=0.4857, \mathrm{p}=0.0003$ ) (Fig. 1).

Although the toxicity effect of the lower dose of $0.5 \mu 1 / \mathrm{cm}^{2} R$. officinalis was not within the framework of what can be considered acceptable in terms of lethal time $\left(\mathrm{LT}_{50}=19 \mathrm{~h}\right.$, $\mathrm{LT}_{95}<24 \mathrm{~h}$ Table 3 ), this concentration of oil does show a repellency effect. When exposed to this concentration of the oil, most of the ticks immediately began to climb the cup wall and then stayed at the top, which is the maximum distance from the oil-impregnated filter paper. This repellency effect decreased gradually over the first three hours, at which point only $40 \%$ of the ticks remained at the top of the cup (Fig. 3). Statistical tests confirmed that the oil has a significant repellency effect against $I$. ricinus ticks $(t=6.793, D F=10$, $\mathrm{R}^{2}=0.8219, \mathrm{p}<0.0001$ ) (Fig. 3). However, the fact that the number of ticks at the top of the cup decreased with increasing exposure time shows that this is not a long-lasting repellency effect as it declines quite sharply after $4 \mathrm{~h}$ of exposure (Fig. 3).

No tick mortality was observed for $1 \mu \mathrm{l} / \mathrm{cm}^{2}$ of $S$. persica oil $(\mathrm{t}=1, \mathrm{df}=10$, $\mathrm{R}^{2}=0.09091, \mathrm{p}=0.34$ ). Thus, $S$. persica oil does not have a significant toxic effect against I. ricinus nymphs. Nonetheless, $S$. persica oil showed a repellency effect against the ticks. At $1 \mu \mathrm{l} / \mathrm{cm}^{2}$ oil, the ticks started to climb the cup's wall immediately. This repellency effect remained at nearly $100 \%$ for at least five hours (Fig. 4), although it had fully disappeared when next checked at $24 \mathrm{~h}$. Statistical testing confirmed that $S$. persica oil at $1 \mu \mathrm{l} / \mathrm{cm}^{2}$ 
Table 2 Compounds present in essential oils of Salvadora persica and Rosmarinus officinalis in alphabetic order within each compound group

\begin{tabular}{|c|c|c|c|}
\hline Compound name & Properties $^{\mathrm{c}}$ & S. persica & R. officinalis \\
\hline \multicolumn{4}{|l|}{ Aliphatics } \\
\hline Hexanal & $\mathrm{P}, \mathrm{R}$ & 3.0 & \\
\hline (2E)-Hexenal & & 32.7 & \\
\hline Hexenal isomer 3 & $\mathrm{P}, \mathrm{R}$ & 3.1 & \\
\hline 2-Nonanone & & 0.1 & \\
\hline \multicolumn{4}{|l|}{ Monoterpene hydrocarbons } \\
\hline Camphene & & & 2.01 \\
\hline p-Cymene & $\mathrm{I}, \mathrm{P}, \mathrm{R}$ & 0.91 & 0.42 \\
\hline 4-Carene & $\mathrm{P}$ & 0.1 & \\
\hline Myrcene & $\mathrm{P}$ & 0.7 & 0.91 \\
\hline Limonene & A, I, P, R & 0.1 & 0.1 \\
\hline$\alpha$-Phellandrene & $\mathrm{P}$ & 0.6 & 0.1 \\
\hline$\alpha$-Pinene & $\mathrm{A}, \mathrm{P}, \mathrm{R}$ & 5.9 & 13.03 \\
\hline$\beta$-Pinene & I, P, R (Oladimeji et al. 2000) & 16.8 & 2.45 \\
\hline Sabinene & I (Park et al. 2003) & 0.8 & \\
\hline$\gamma$-Terpinene & & & 1.14 \\
\hline Terpinolene & & & 0.94 \\
\hline \multicolumn{4}{|l|}{ Oxygenated monoterpenes } \\
\hline $\begin{array}{l}\text { Bicyclo(2,2,1) heptan-3-one 6,6-methyl- } \\
\text { 2-methylene }\end{array}$ & & 2.36 & \\
\hline Borneol & & & 7.08 \\
\hline Bornyl acetate & & 0.1 & 6.27 \\
\hline$\alpha$-Campholenal & & 0.1 & \\
\hline Camphor & & & 4.55 \\
\hline Chrysantenone & & & 0.51 \\
\hline 1,8-Cineol & $\mathrm{P}, \mathrm{R}$ & 20.8 & 24.07 \\
\hline Citronellol & & & 0.22 \\
\hline 6,6-Dimethyl-2-norpinene-2-carboxaldehyde & & 2.0 & \\
\hline Geranial & & & 0.47 \\
\hline Geranyl acetate & & & 0.56 \\
\hline Linalool & & & 3.7 \\
\hline$p$-Ment-4(8)-en-3-on & & 0.1 & \\
\hline Myrtenol & & 1.97 & 0.61 \\
\hline Nerol & & & 6.12 \\
\hline Isopinocampheol & & 1.97 & 0.48 \\
\hline Isopinocamphone & & 1.2 & 0.95 \\
\hline Terpinene-4-ol & P, R (Ndungu et al. 1995) & & 1.39 \\
\hline$\alpha$-Terpineol & & & 3.66 \\
\hline cis- $\beta$-Terpineol & & & 0.68 \\
\hline Thujone & & 0.7 & \\
\hline cis-Verbenol & $\mathrm{R}$ & 0.2 & \\
\hline Verbenone & & & 11.51 \\
\hline \multicolumn{4}{|l|}{ Sesquiterpenes } \\
\hline$\beta$-Bourbonene & & 0.1 & \\
\hline
\end{tabular}


Table 2 (continued)

\begin{tabular}{llcc}
\hline Compound name & Properties $^{\mathrm{c}}$ & S. persica & R. officinalis \\
\hline Unknown sesquiterpene & & 0.8 & \\
$\begin{array}{l}\beta \text {-Caryophyllene } \\
\quad \text {-Caryophyllene oxide }\end{array}$ & P, R, I & & 1.37 \\
Aromatics & I, P, R & 0.2 & 0.44 \\
Eugenol & & & \\
$\quad$ Methyl salicylate & A, P & 0.1 & \\
Total no. of identified compounds & & 0.5 & \\
Total \% of identified compounds & & 28 & 28 \\
& & 98.01 & 98.23 \\
\hline
\end{tabular}

Mortality rates for nymphs of I.ricinus exposued to $R$. officinali oil for $24 \mathrm{~h}$

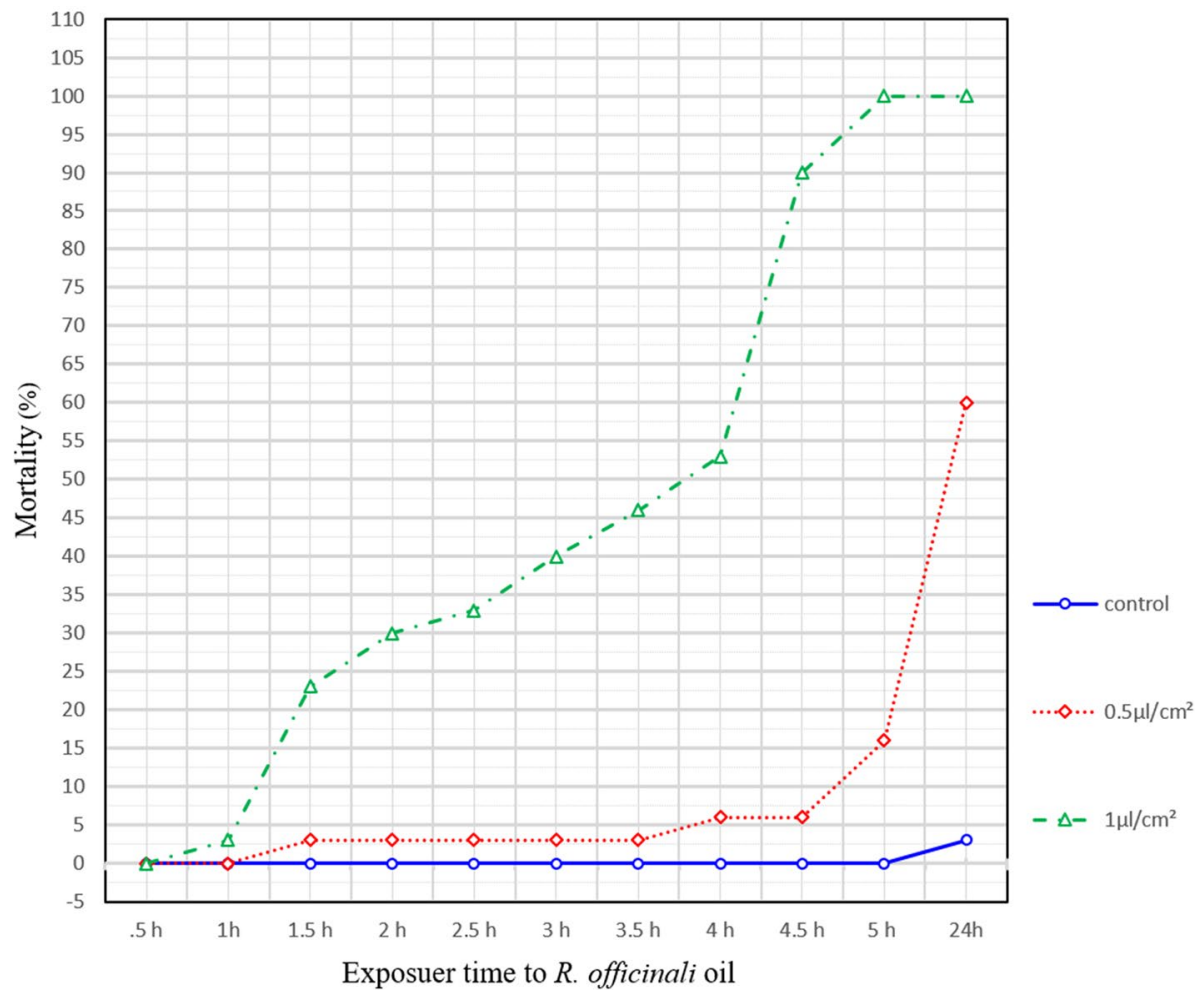

Fig. 1 Mortality of Ixodes ricinus nymphs exposed to Rosmarinus officinalis oil over 24 h. Ixodes ricinus nymphs were exposed to 0 (control), 0.5 and $1.0 \mu \mathrm{l} / \mathrm{cm}^{2}$ of $R$. officinalis oil. Nymph mortality was recorded every $0.5 \mathrm{~h}$ over a $5 \mathrm{~h}$ period and then again at $24 \mathrm{~h}, \mathrm{LT}_{50}$ and $\mathrm{LT}_{95}$ were calculated from this graph (Table 3)

has a significant repellency effect against $I$. ricinus tick $\left(\mathrm{t}=9.977, \mathrm{df}=10, \mathrm{R}^{2}=0.9087\right.$, $\mathrm{p}<0.0001$; Fig. 4$)$. At $1.5 \mathrm{~h}$, the $95 \%$ repellency concentration $\left(\mathrm{RC}_{95}\right)$ was estimated at $0.95 \mu \mathrm{l} / \mathrm{cm}^{2}$ or roughly $1 \mu \mathrm{l} / \mathrm{cm}^{2}$ of $S$. persica oil. Meanwhile the $\mathrm{RT}_{95}$ for $1 \mu \mathrm{l} / \mathrm{cm}^{2}$ of $S$. 
Time-response curves for different exposure times to $R$. officinalis oil.

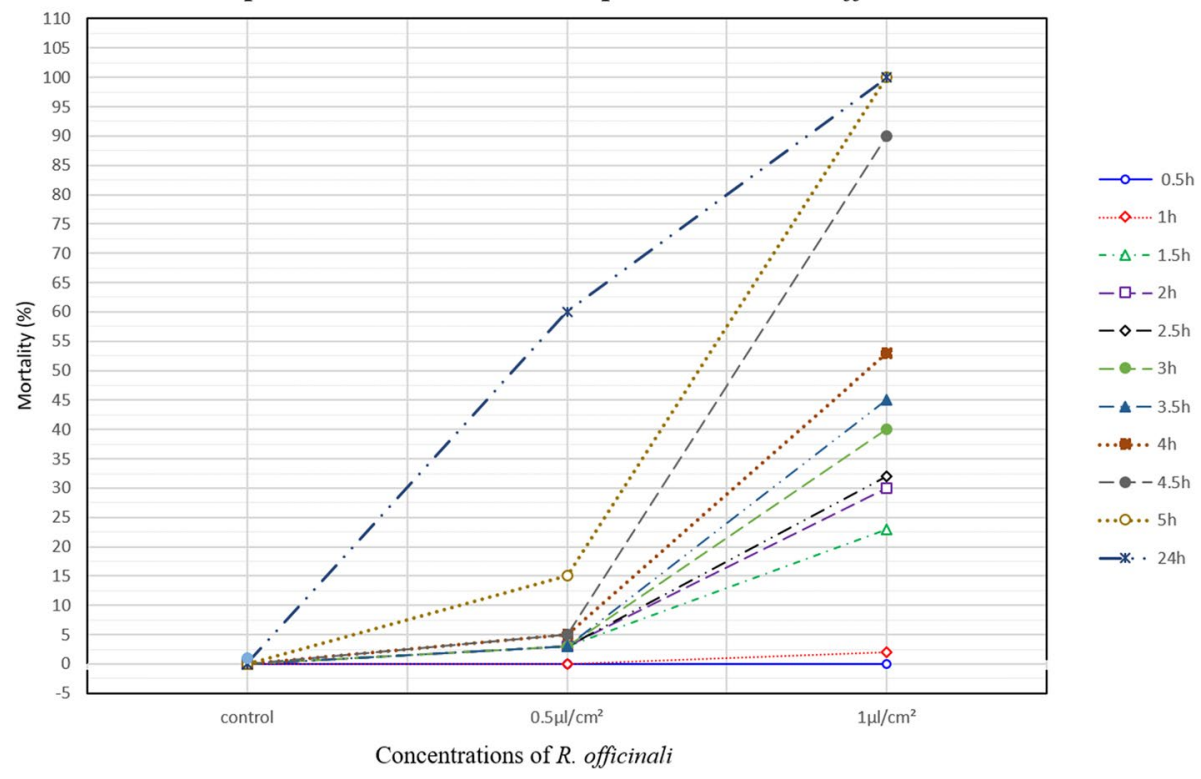

Fig. 2 Time-response curves for different exposure times to Rosmarinus officinalis oil. The $\mathrm{LC}_{50}$ and $\mathrm{LC}_{95}$ of $R$. officinalis oil against Ixodes ricinus nymphs were calculated from the curves for different exposure times shown in the graph

Table 3 Predicted lethal concentrations (LC) at different exposure times (ET) and lethal times (LT) at different concentrations of Rosmarinus officinalis oil against Ixodes ricinus

\begin{tabular}{|c|c|c|c|c|c|}
\hline \multicolumn{3}{|c|}{ Lethal concentrations (LC) } & \multicolumn{3}{|c|}{ Lethal times (LT) } \\
\hline $\begin{array}{l}\text { ET to } \\
\text { ROO }\end{array}$ & $\mathrm{LC}_{50}$ & $\mathrm{LC}_{95}$ & $\begin{array}{l}\text { Conc. of } \\
\text { ROO }\end{array}$ & $\mathrm{LT}_{50}$ & $\mathrm{LT}_{95}$ \\
\hline $4 \mathrm{~h}$ & $0.95 \mu \mathrm{l} / \mathrm{cm}^{2}$ & - & $0.5 \mu \mathrm{l} / \mathrm{cm}^{2}$ & $19 \mathrm{~h}$ & - \\
\hline $4.5 \mathrm{~h}$ & $0.75 \mu \mathrm{l} / \mathrm{cm}^{2}$ & - & $1 \mu \mathrm{l} / \mathrm{cm}^{2} *$ & $3.5-4 \mathrm{~h}$ & $4.5-5 \mathrm{~h}$ \\
\hline $5 \mathrm{~h}^{*}$ & $0.7 \mu 1 / \mathrm{cm}^{2}$ & $0.95 \mu \mathrm{l} / \mathrm{cm}^{2}$ & & & \\
\hline $24 \mathrm{~h}$ & $0.4 \mu 1 / \mathrm{cm}^{2}$ & $0.9 \mu \mathrm{l} / \mathrm{cm}^{2}$ & & & \\
\hline
\end{tabular}

*At $5 \mathrm{~h} \mathrm{LC} \mathrm{LC}_{95}=0.95 \mu \mathrm{l} / \mathrm{cm}^{2}$ of $R$. officinalis $\approx 1 \mu \mathrm{l} / \mathrm{cm}^{2}$ of $R$. officinalis, and at $1 \mu \mathrm{l} / \mathrm{cm}^{2}$ of $R$. officinalis $\mathrm{LT}_{95}=4.5 \mathrm{~h} \approx 5 \mathrm{~h}$. the data was calculated from the curves for different exposure times shown in Fig. 2. The curves of different concentrations shown in Fig. 1

persica oil was estimated at $5 \mathrm{~h}$ (Fig. 4). Thus, $S$. persica oil appears to have nearly complete repellency against I. ricinus nymphs for around $5 \mathrm{~h}$.

\section{Discussion}

We have studied the toxicity and repellency of $R$. officinalis and S. persica essential oils against nymphs of the common tick, I. ricinus. Our results show that $R$. officinalis has both significant toxicity (Fig. 1, Fig. 2) and significant repellency (Fig. 3) effects against the ticks (Table 3), while S. persica exhibits significant repellency (Fig. 4). 


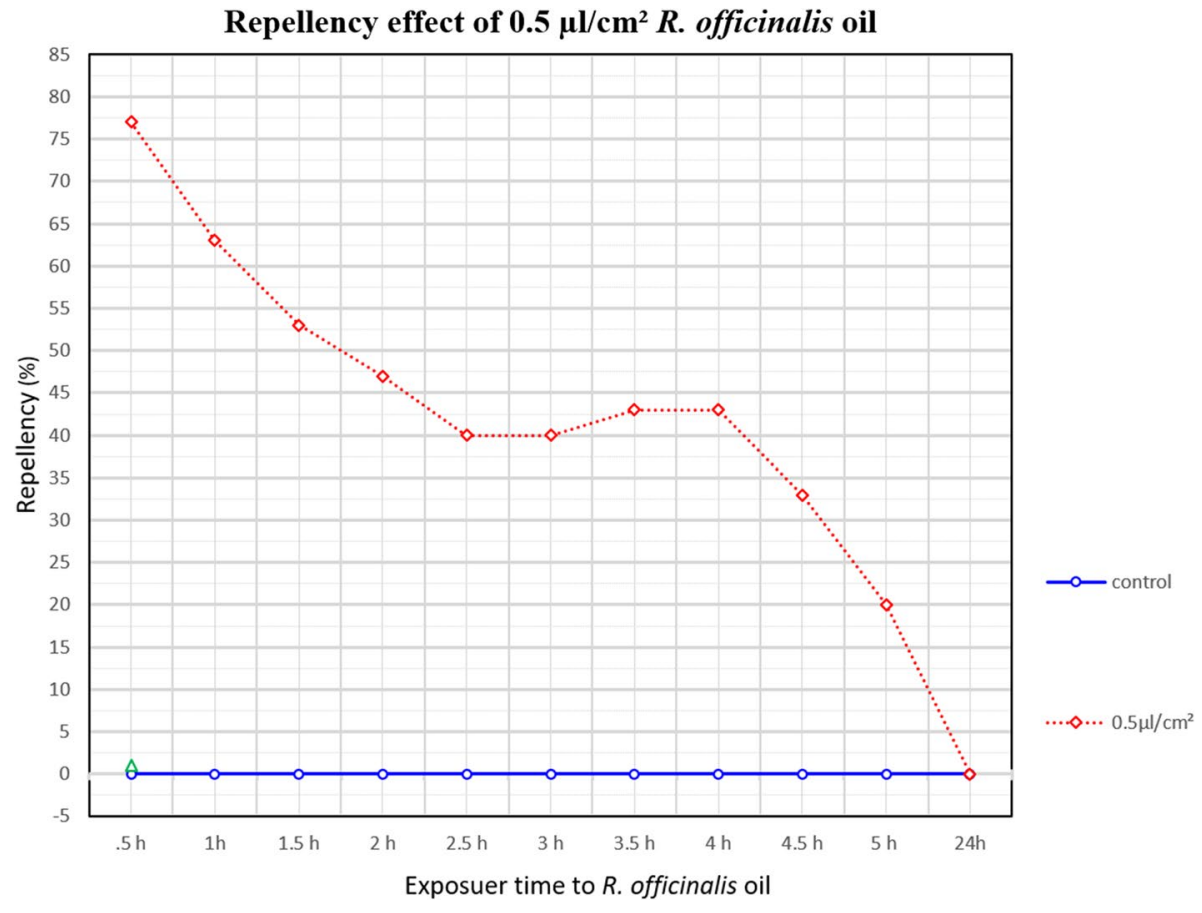

Fig. 3 Repellency effect of $0.5 \mu \mathrm{l} / \mathrm{cm}^{2}$ Rosmarinus officinalis oil against Ixodes ricinus nymph exposed for $24 \mathrm{~h}$. Repellency (\%) effect of $0.5 \mu \mathrm{l} / \mathrm{cm}^{2}$ concentration of $R$. officinalis oil during different exposure times (hours) against I. ricinus nymphs

GC-MS analysis indicates that the oils have major compounds in common, especially the main monoterpene hydrocarbons 1,8-cineol, $\alpha$-pinene, and $\beta$-pinene, although these are present in different proportions in the two oils (Table 2). Both oils also have a small amount of $\beta$-caryophyllene oxide which previous work has shown to have acaricidal activity against Dermatophagoides farinae and D. pteronyssinus (house dust mites) (Oh et al. 2014).

In Libya, in the past, people built their tents beside $S$. persica plants to avoid insects and Acari (El-Mogrebi 2003). The fresh leaves are also used in traditional medicine for treating coughs, asthma, scurvy, rheumatism, piles and other diseases. The flowers are small and fragrant, are used as a stimulant, and are mildly purgative. Extracts of the leaves have been shown to have a considerable anti-bacterial effect on several different aerobic oral bacteria (Alali and Al-Lafi 2003).

The essential oil of $S$. persica possesses highly effective repellency against $I$. ricinus nymphs. In fact, this repellency was nearly $100 \%$ for at least $5 \mathrm{~h}$, although it had reached zero by $24 \mathrm{~h}$. Several of the monoterpenes present in $S$. persica essential oil (Table 2) are known to be effective tick repellent compounds. These are also more stable compared to the highly volatile $\alpha$ - and $\beta$-pinene found in $R$. officinalis and can thus explain the more long lasting effect of the $S$. persica oil. This is also consistent with previous work showing a repellent effect of S. persica against I. ricinus at higher doses (Garboui et al. 2009). In fact, the present study shows repellency activity of $S$. persica with a ten times lower dose than the previous work. 


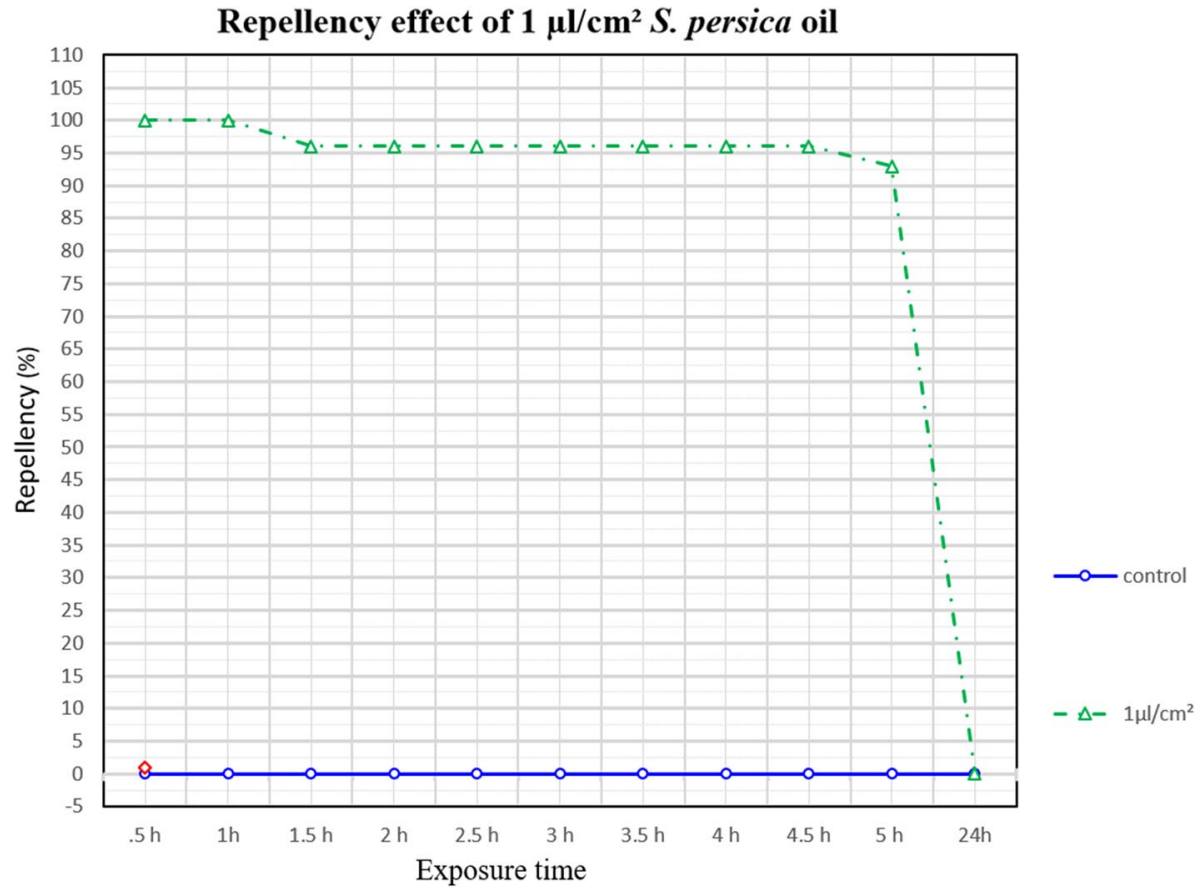

Fig. 4 Repellency effect of $1 \mu \mathrm{l} / \mathrm{cm}^{2}$ Salvadora persica oil against Ixodes ricinus nymphs exposed for $24 \mathrm{~h}$. Repellency (\%) effect of $1 \mu \mathrm{l} / \mathrm{cm}^{2}$ concentration of $S$. persica oil during different exposure times (hours) against $I$. ricinus nymphs

The major constituents of $S$. persica leaf essential oil are (2E)-Hexenal (32.7\%) and 1,8-cineole (20.8\%) followed by $\beta$-pinene (16.8\%) and $\alpha$-pinene (5.9). Repellency effects of 1,8 -cineole have been previously reported, but this work found the oil to be too volatile to be used in ten times lower dose (Pålsson et al. 2008). This compound (1,8-cineole) has also been shown to act as a repellent against several species of insects, particularly the nymphs of the German cockroach (Liu et al. 2011), stored product insects (Yoon et al. 2007) and the mosquito, Culex pipiens (Traboulsi et al. 2002). Previous work has also shown that $\alpha$-pinene isolated from the essential oil of Dianthus caryophyllum exhibits a strong repellent effect against ticks (I. ricinus) (Tunón et al. 2006).

In North African countries, $R$. officinalis is highly prized for its essential oil and its biological properties. It is the most abundantly exported herb, in the region constituting approximately $12.70 \%$ of all dried herb and medicinal plant exports (Hufbauer and Brunel 2009). In Libya, wild rosemary is very common and is used locally especially in the high Green Mountain (Al Jabil Al Akhder). Since ancient times it has been used for medicinal purposes and is known for its antibacterial (Okoh et al. 2010), antifungal (Sertkaya et al. 2010) and insecticidal (Zoubiri and Baaliouamer 2011) properties. Our study shows that $R$. officinalis oil has significant acaricide activity in the laboratory. This is consistent with previous work showing that Rosemary oil produces $>85 \%$ larval mortality in the Asian blue tick, Rhipicephalus (Boophilus) microplus (Martinez-Velazquez et al. 2011). The aromatic vapour of rosemary oil has also been shown to have ovicidal and larvicidal effects against several stored product pests (Papachristos and Stamopoulos 2004) (Tunc et al. 2000) and to 
function as fumigant against the two-spotted spider mite (Tetranychus urticae) Koch (Cho et al. 2004). The oil can have a sublethal effect as well, for example acting as a repellent to onion thrips, Thrips tabaci Lind (Koschier and Sedy 2003) and as well as nymphs of $I$. ricinus (Fig. 3) and (El-Seedi et al. 2012).

Most of the compounds were identified by GC-MS and are monoterpenes e.g. 1,8-cineole, $\alpha$-pinene, camphor and borneol, all of which are known to have repellent activity and which together are the major constituents of $R$. officinalis essential oil (Table 2). This result is in agreement with previous work (El-Seedi et al. 2012; Martinez-Velazquez et al. 2011; Schubert et al. 2017). The acaricidal activity of essential oils has previously been attributed to the presence of constituents such as 1.8-cineole (Cavalcanti et al. 2010) (Hüe et al. 2015). Essential oils from Eucalyptus globulus and its major monoterpene 1,8-cineole showed toxicity against human head lice (Yang et al. 2004). However, despite the abundance of this compound in S. persica oil (20.8\%, Table 2), this oil did not show toxicity to the ticks in our study in comparison to $R$. officinalis. This may be due to that the presence of oxygenated monoterpenes (such as Verbenone and Borneol) is much higher in the content of $R$. officinalis. Another prominent constituent of both oils was $\alpha$-pinene, which has also been shown to produce strong acute toxicity against Pear psylla (Nyabayo et al. 2015). This compound has also been extracted from Laurus novocanariensis essential oil and demonstrated to have potent acaricidal activity against Psoroptes cuniculi mites with $100 \%$ mortality (Macchioni et al. 2006). Additionally, acaricide doses close to the $\mathrm{LC}_{50}$ with lower dose $0.5 \mu \mathrm{l} / \mathrm{cm}^{2}$, it could induce rather delayed toxification and survival of toxemic ticks for several days (syndrome of a slow death according to Uspenskiy (Uspenskiy 1982).

\section{Conclusion}

We found that both of the oils used in this study have effects against I. ricinus ticks. S. persica oil had a stronger and longer-lasting repellency effect than $R$. officinalis oil; while only $R$. officinalis oil had a significant toxic effect against $I$. ricinus ticks. GC-MS shows that both oils have large concentrations of similar terpenes. Thus, the different ratios of these terpenes in the different oils may account for the differences in their effects against ticks.

Acknowledgements We thank T. G. T Jaenson (Uppsala University) for the help provided during the experiments and K. Pålsson (KTH) for the help in statistical analysis. I (FE) am grateful to The Ministry of Higher Education and Scientific Research of Libya for funding this work.

Open Access This article is distributed under the terms of the Creative Commons Attribution 4.0 International License (http://creativecommons.org/licenses/by/4.0/), which permits unrestricted use, distribution, and reproduction in any medium, provided you give appropriate credit to the original author(s) and the source, provide a link to the Creative Commons license, and indicate if changes were made.

\section{References}

Aberer E (2009) What should one do in case of a tick bite? Lyme borreliosis, vol 37. Karger Publishers, Basel, pp 155-166 
Alali F, Al-Lafi T (2003) Gc-ms analysis and bioactivity testing of the volatile oil from the leaves of the toothbrush tree Salvadora persica 1. Nat Prod Res 17:189-194

Begum A, Sandhya S, Ali SS, Vinod KR, Reddy S, Banji D (2013) An in-depth review on the medicinal flora Rosmarinus officinalis (lamiaceae). Acta scientiarum polonorum Technologia alimentaria 12(1):61-74

Bischof LJ, Enan EE (2004) Cloning, expression and functional analysis of an octopamine receptor from Periplaneta americana. Insect Biochem Mol Biol 34:511-521. https://doi.org/10.1016/j. ibmb.2004.02.003

Bueno-Marí R (2013) Looking for new strategies to fight against mosquito-borne diseases: toward the development of natural extracts for mosquito control and reduction of mosquito vector competence. Front Physiol 4:20

Bueno-Marí R, Almeida A, Navarro JC (2015) Emerging zoonoses: eco-epidemiology, involved mechanisms, and public health implications. Front Public Health 3:157

Cavalcanti S, Niculau ED, Blank A, Câmara C, Araújo I, Alves P (2010) Composition and acaricidal activity of Lippia sidoides essential oil against two-spotted spider mite (Tetranychus urticae koch). Bioresour Technol 101:829-832

Centers for disease control and prevention (cdc) (2017) Tickborne disease surveillance data summary. https ://www.cdc.gov/ticks/data-summary/index.html

Cho WI, Lee SG, Park HM, Ahn YJ (2004) Toxicity of plant essential oils to Tetranychus urticae (acari : Tetranychidae) and Phytoseiulus persimilis (acari : Phytoseiidae). J Econ Entomol 97:553-558. https://doi.org/10.1093/jee/97.2.553

Cook MJ (2015) Lyme borreliosis: a review of data on transmission time after tick attachment. Int J Gen Med 8:1

El-Mogrebi EGAAM (2003) Usages of plants in libyan folk-medicine. In: El-Mogrebi EGAAM (ed). vol 3. Libyan university, Zaouia

El-Seedi HR, Khalil NS, Azeem M, Taher EA, Göransson U, Pålsson K, Borg-Karlson A-K (2012) Chemical composition and repellency of essential oils from four medicinal plants against Ixodes ricinus nymphs (acari: Ixodidae). J Med Entomol 49:1067-1075. https://doi.org/10.1603/ME11250

Estrada-Peña A, Jongejan F (1999) Ticks feeding on humans: a review of records on human-biting ixodoidea with special reference to pathogen transmission. Exp Appl Acarol 23:685-715. https://doi. org/10.1023/a:1006241108739

Estrada-Peña A, Mihalca AD, Petney TN (2018) Ticks of Europe and North Africa: a guide to species identification. Springer, New York

Garboui SS, Borg-Karlson AK, Pålsson K (2009) Tick repellent properties of three libyan plants. J Med Entomol 46:1415-1419. https://doi.org/10.1603/033.046.0623

Ghosh S, Azhahianambi P, Yadav M (2007) Upcoming and future strategies of tick control: a review. J Vector Borne Dis 44:79

Heyman P, Cochez C, Hofhuis A, Van Der Giessen J, Sprong H, Porter SR, Losson B, Saegerman C, Donoso-Mantke O, Niedrig M (2010) A clear and present danger: tick-borne diseases in Europe. Expert Rev Anti-infective Ther 8:33-50

Hüe T, Cauquil L, Fokou JBH, Dongmo PMJ, Bakarnga-Via I, Menut C (2015) Acaricidal activity of five essential oils of Ocimum species on Rhipicephalus (boophilus) Microplus larvae. Parasitol Res 114:91-99. https://doi.org/10.1007/s00436-014-4164-6

Hufbauer GC, Brunel C (2009) Capitalizing on the morocco-us free trade agreement: a road map for success. Peterson Institute, Washington, DC

Hynote ED, Mervine PC, Stricker RB (2012) Clinical evidence for rapid transmission of lyme disease following a tickbite. Diagn Microbiol Infect Dis 72:188-192

Isman MB, Koul O, Luczynski A, Kaminski J (1990) Insecticidal and antifeedant bioactivities of neem oils and their relationship to Azadirachtin content. J Agric Food Chem 38:1406-1411

Jaenson TG, Hjertqvist M, Bergström T, Lundkvist $\AA$ (2012) Why is tick-borne encephalitis increasing? A review of the key factors causing the increasing incidence of human tbe in sweden. Parasites Vectors 5:184

Jongejan F, Uilenberg G (2004) The global importance of ticks. Parasitology 129:S3-S14

Koschier EH, Sedy KA (2003) Labiate essential oils affecting host selection and acceptance of thrips Tabaci lindeman. Crop Prot 22:929-934. https://doi.org/10.1016/s0261-2194(03)00092-9

Kostyukovsky M, Rafaeli A, Gileadi C, Demchenko N, Shaaya E (2002) Activation of Octopaminergic receptors by essential oil constituents isolated from aromatic plants: possible mode of action against insect pests. Pest Manag Sci 58:1101-1106. https://doi.org/10.1002/ps.548

Lindgren E, Gustafson R (2001) Tick-borne encephalitis in Sweden and climate change. Lancet 358:1618. https://doi.org/10.1016/S0140-6736(00)05250-8 
Lindgren E, Tälleklint L, Polfeldt T (2000) Impact of climatic change on the northern latitude limit and population density of the disease-transmitting european tick Ixodes ricinus. Environ Health Perspect 108:119-123

Liu ZL, Yu M, Li XM, Wan T, Chu SS (2011) Repellent activity of eight essential oils of chinese medicinal herbs to blattella germanica 1. Rec Nat Prod 5:176-183

Macchioni F, Perrucci S, Cioni P, Morelli I, Castilho P, Cecchi F (2006) Composition and acaricidal activity of Laurus novocanariensis and Laurus nobilis essential oils against Psoroptes cuniculi. J Essent Oil Res 18:111-114. https://doi.org/10.1080/10412905.2006.9699403

Mannelli A, Bertolotti L, Gern L, Gray J (2012) Ecology of Borrelia burgdorferi sensu lato in Europe: transmission dynamics in multi-host systems, influence of molecular processes and effects of climate change. FEMS Microbiol Rev 36:837-861

Martinez-Velazquez M, Castillo-Herrera GA, Rosario-Cruz R, Flores-Fernandez JM, Lopez-Ramirez J, Hernandez-Gutierrez R, del Carmen Lugo-Cervantes E (2011) Acaricidal effect and chemical composition of essential oils extracted from Cuminum cyminum, Pimenta dioica and Ocimum basilicum against the cattle tick Rhipicephalus (boophilus) Microplus (acari: Ixodidae). Parasitol Res 108:481-487

Medlock JM, Hansford KM, Bormane A, Derdakova M, Estrada-Peña A, George J-C, Golovljova I, Jaenson TG, Jensen J-K, Jensen PM (2013) Driving forces for changes in geographical distribution of Ixodes ricinus ticks in Europe. Parasites Vectors 6:1

Mejlon HA, Jaenson TGT (1993) Seasonal prevalence of Borrelia burgdorferi in Ixodes ricinus in different vegetation types in Sweden. Scand J Infect Dis 25:449-456. https://doi.org/10.3109/00365 549309008526

Michelet L, Delannoy S, Devillers E, Umhang G, Aspan A, Juremalm M, Chirico J, van der Wal FJ, Sprong H, Boye Pihl TP, Klitgaard K, Bodker R, Fach P, Moutailler S (2014) High-throughput screening of tick-borne pathogens in Europe. Front Cell Infect Microbiol 4:103. https://doi. org/10.3389/fcimb.2014.00103

Ndungu M, Lwande W, Hassanali A, Moreka L, Chhabra SC (1995) Cleome monophylla essential oil and its constituents as tick (Rhipicephalus appendiculatus) and maize weevil (Sitophilus zeamais) repellents. Entomol Exp Appl 76:217-222

Nyabayo CT, Matasyoh JC, Mwendia C (2015) Chemical composition and acaricidal activity of salvia nilotica essential oil against Rhipicephalus appendiculatus. Adv Medicinal Plant Res 3:46-54

Oh MS, Yang JY, Kim MG, Lee HS (2014) Acaricidal activities of $\beta$-caryophyllene oxide and structural analogues derived from Psidium cattleianum oil against house dust mites. Pest Manag Sci 70:757-762

Okoh O, Sadimenko A, Afolayan A (2010) Comparative evaluation of the antibacterial activities of the essential oils of Rosmarinus officinalis 1. Obtained by Hydrsodistillation and solvent free microwave extraction methods. Food Chem 120:308-312

Oladimeji F, Orafidiya O, Ogunniyi T, Adewunmi T (2000) Pediculocidal and scabicidal properties of Lippia multiflora essential oil. J Ethnopharmacol 72:305-311

Oris JT, Bailer AJ (1997) Equivalence of concentration-response relationships in aquatic toxicology studies: testing and implications for potency estimation. Environ Toxicol Chem 16:2204-2209

Pålsson K, Jaenson TGT, Bæckström P, Borg-Karlson A-K (2008) Tick repellent substances in the essential oil of Tanacetum vulgare. J Med Entomol 45:88-93. https://doi.org/10.1093/jmedent/45.1.88

Papachristos DP, Stamopoulos DC (2004) Fumigant toxicity of three essential oils on the eggs of Acanthoscelides obtectus (say) (Coleoptera : Bruchidae). J Stored Prod Res 40:517-525. https://doi. org/10.1016/j.jspr.2003.07.002

Park I-K, Lee S-G, Choi D-H, Park J-D, Ahn Y-J (2003) Insecticidal activities of constituents identified in the essential oil from leaves of Chamaecyparis obtusa against Callosobruchus chinensis (L.) and Sitophilus oryzae (L.). J Stored Prod Res 39:375-384

Pritt BS, Respicio-Kingry LB, Sloan LM, Schriefer ME, Replogle AJ, Bjork J, Liu G, Kingry LC, Mead PS, Neitzel DF (2016) Borrelia mayonii sp. Nov., a member of the Borrelia burgdorferi sensu lato complex, detected in patients and ticks in the upper midwestern United States. Int J Syst Evolut Microbiol 66:4878-4880

Randolph SE (1998) Ticks are not insects: consequences of contrasting vector biology for transmission potential. Parasitol Today 14:186-192. https://doi.org/10.1016/S0169-4758(98)01224-1

Schubert F, Pålsson K, Santangelo E, Borg-Karlson A-K (2017) Sulfate turpentine: a resource of tick repellent compounds. Exp Appl Acarol 72:291-302

Sertkaya E, Kaya K, Soylu S (2010) Acaricidal activities of the essential oils from several medicinal plants against the carmine spider mite (Tetranychus cinnabarinus boisd.) (Acarina: Tetranychidae). Ind Crops Prod 31:107-112 
Sofrata AH (2010) Salvadora persica (miswak): an effective way of killing oral pathogens, Institutionen för odontologi/Department of Odontology

Strle F, Nelson JA, Ruzic-Sabljic E, Cimperman J, Maraspin V, Lotric-Furlan S, Cheng Y, Picken MM, Trenholme GM, Picken RN (1996) European lyme borreliosis: 231 culture-confirmed cases involving patients with Erythema migrans. Clin Infect Dis 23:61-65

Stroh J, Wan M, Isman M, Moul D (1998) Evaluation of the acute toxicity to juvenile pacific coho salmon and rainbow trout of some plant essential oils, a formulated product, and the carrier. Bull Environ Contamin Toxicol 60:923-930

Traboulsi AF, Taoubi K, El-Haj S, Bessiere JM, Rammal S (2002) Insecticidal properties of essential plant oils against the mosquito culex Pipiens molestus (Diptera: Culicidae). Pest Manag Sci 58:491-495

Tunc I, Berger BM, Erler F, Dagli F (2000) Ovicidal activity of essential oils from five plants against two stored-product insects. J Stored Prod Res 36:161-168. https://doi.org/10.1016/s0022-474x(99)00036-3

Tunón H, Thorsell W, Mikiver A, Malander I (2006) Arthropod repellency, especially tick (Ixodes ricinus), exerted by extract from Artemisia abrotanum and essential oil from flowers of Dianthus caryophyllum. Fitoterapia 77:257-261

Uspenskiy I (1982) Susceptibility to acaricides of adult Ornithodoros tholozani (ixodoidea: Argasidae) in relation to the slow-death syndrome. J Med Entomol 19:701-705

Wang Z, Yan H, Yang Y, Wu Y (2010) Biotype and insecticide resistance status of the whitefly Bemisia tabaci from China. Pest Manag Sci 66:1360-1366

WHO U (1996) Report of the who informal consultation on the" evaluation and testing of insecticides", who/hq, geneva, 7 to 11 october 1996. Geneva: World Health Organization

Yang Y-C, Lee H-S, Clark JM, Ahn Y-J (2004) Insecticidal activity of plant essential oils against pediculus Humanus capitis (anoplura: Pediculidae). J Med Entomol 41:699-704. https://doi. org/10.1603/0022-2585-41.4.699

Yoon C, Kang S-H, Jang S-A, Kim Y-J, Kim G-H (2007) Repellent efficacy of caraway and grapefruit oils for Sitophilus oryzae (coleoptera: Curculionidae). J Asia-Pac Entomol 10:263-267

Zoubiri S, Baaliouamer A (2011) Chemical composition and insecticidal properties of some aromatic herbs essential oils from Algeria. Food Chem 129:179-182

Publisher's Note Springer Nature remains neutral with regard to jurisdictional claims in published maps and institutional affiliations. 